\title{
Akrasia and the Desire to Become Someone Else: Venturinha on Moral Matters
}

\section{Javier González de Prado*}

Nuno Venturinha's book, Descriptions of Situations, provides a concise, but remarkably wide-ranging account of language and thought from what can be called a practice-based perspective. This type of perspective takes as its starting point the situated study of our discursive practices in particular contexts. One of the main challenges faced by such an approach, as I see it, is to show how our practices can come to be governed by objective standards, that is standards that go beyond the evaluative stances of the participants in the practice.

This challenge is especially pressing in relation to moral practices, the topic of the last chapter of Venturinha's book. Our epistemic practices concerning empirical issues involve perception and practical interactions with our surroundings, which arguably introduce sufficient friction with the world for objective standards to arise. It is not obvious what could play an analogous role to perception in the case of moral thought (one can perhaps argue that moral intuitions bring us into contact with objective, mindindependent moral facts, but this is surely a controversial idea). Not surprisingly, therefore, it has been common in the literature to endorse some form of non-objectivism about our moral practices. Instances of such non-objectivism can be found in different versions of moral emotivism, relativism, expressivism and constructivism (see, among many others, Ayer 1936/1971; Stevenson 1944; Hartman 1975; Blackburn 1984, 1993; Gibbard 1992; Street 2010).

In this note, my goal is to discuss akrasia from the perspective of the sophisticated form of moral subjectivism that, I think, can be derived from Venturinha's remarks on moral matters. In order to do so, I start by examining Venturinha's Disclosure Principle and the type of subjectivism it leads to. Then I critically discuss Venturinha's epistemic account of akrasia and I propose what I take to be a better alternative view, based on the

\footnotetext{
$\triangle$ Javier González de Prado

jgonzalezdeprado@fsof.uned.es

1 Department of Logic, Philosophy and History of Science, UNED, Madrid, Spain
} 
Disclosure Principle. According to this proposal, in an akratic subject there is a conflict between the motivational dispositions she currently has, as the person she is now, and the motivational dispositions that the person she aspires to be would have.

\section{The Ethical and the Subjective}

At first sight, it could seem that Venturinha embraces a purely subjectivist view of moral practices, or at least of what he calls the ethical. Indeed, he starts the chapter distinguishing between "morality", understood as the social norms mandatory in a community, and "ethics", which is related to the pursuit of the good and has to do with an inner space of intimacy and a first-person stance: "Ethics, one could say, is my own business; morality is communitarian" (Venturinha 2018: 90). However, it soon becomes apparent that what Venturinha calls the ethical incorporates an inter-subjective dimension. Ethics is after all communitarian at root.

The inter-subjective nature of the ethical is reflected in Venturinha's Disclosure Principle (2018: 91). According to this principle, one should act as if one's actions were being observed and assessed by people one cares for: "imagine that whatever you do, even the things that only you know about, can be seen and would be seen by those you most care for" (Venturinha 2018: 91). Clearly, the Disclosure Principle is implausible as a principle determining what is (ethically) right: it is too dependent on contingent issues about who those you care for are and what moral sensibilities and judging dispositions they actually have. For instance, it could happen that you care very much for your loved ones despite knowing that they have terrible ethical views. It could even be the case that you know that you tend to behave badly when you are observed by your loved ones (perhaps because you feel under pressure to conform to their terrible ethical views).

However, I do not think that we are supposed to understand the Disclosure Principle in this strong (and implausible) way. The principle should rather be taken to provide a fallible heuristic guide for figuring out what the right thing to do is. Seen under this light, the principle becomes more attractive. Moreover, the Disclosure Principle points to a way of avoiding extreme subjectivism, by introducing a wedge between the subject's desires and what is actually ethically right. The principle makes room for the possibility that the subject desires to do something that is actually wrong, since what she desires can be at odds with what those she cares for would approve of. 
In this way, I propose reading the Disclosure Principle as underlain by a responsedependent account of ethical goodness and rightness (Wiggins 1987; Lewis 1989; Wegwood 1997; McDowell 1998). The idea behind the principle would be that ethically right actions are those that would be approved of by judges that the subject considers creditable or worth listening to. In other words, the good would be what the subject considers to be worthy of being valued - and right actions would be those actions that the subject considers that deserve being approved of. This version of the principle comes close to a fitting-attitudes view of value, according to which being of value amounts to being the fitting object of valuing attitudes like approval (see Wiggins 1987; McDowell 1998; Scanlon 1998). However, note that the principle I am gesturing towards stops short of being a fully-fledged fitting-attitudes account, given that what is ethically good would be determined by those evaluative responses that the subject considers to be fitting, rather than by the responses that are actually fitting.

To be sure, we could take one further step and claim that ethically good actions are those that are the object of fitting attitudes of approval. But I am not sure whether Venturinha is willing to go this far. As I see it, a view that is closer to the spirit of Venturinha's Disclosure Principle is David Lewis' proposal that what is good is what the subject desires to desire (Lewis 1989). Plausibly, in general we will desire to have those desires and evaluative attitudes that we consider fitting or appropriate, that is the evaluative attitudes that those who we take to be admirable ethical judges are disposed to have. As pointed out above, this type of view goes beyond a crude form of ethical subjectivism, insofar as it allows for ethical evaluation to take some distance from the subject's immediate first-order desires and evaluative attitudes. Granted, the view is not fully objectivist, since it does not distinguish between what is fitting to value or desire and what the subject desires to value or desire. But perhaps full objectivity is not to be had in the ethical realm. At any rate, I think that the Disclosure Principle does not (and is not expected to) secure robust ethical objectivity, but just a moderate form of (inter)subjectivism.

\section{Akrasia as an Epistemic Problem}

Although the Disclosure Principle may offer some guide in ethical deliberations, it does not seem that Venturinha thinks that it always provides conclusive answers about what to 
do on particular occasions. Indeed, Venturinha suggests that ethical uncertainty is widespread: it is often difficult to figure out exactly what one ought to do in a certain situation (2018: 93). The reason for this is that, according to Venturinha, ethical deliberation is highly context-sensitive. From this particularist conception of ethics, Venturinha draws the sceptical conclusion that ethical knowledge is typically not forthcoming: "Again, there can be no such thing as moral knowledge. The positive and negative poles of the ethical experience simply indicate a momentary state of consciousness that is context-sensitive." (2018: 93)

Venturinha derives an interesting epistemic account of akrasia from his ethical scepticism. Akrasia is said by Venturinha to take place when the subject chooses "to do what she judges to be wrong instead of what she judges to be right" (2018: 92). However, in Venturinha's view, akrasia is actually the result of ethical uncertainty. When a subject does $w$ rather than what she judges she ought to do, $r$, it is because she does not really know for sure whether doing $r$ is better than doing $w$ :

She does $w$ for the simple reason that she is not absolutely sure about the value of $r$. She may be more inclined to believe that doing $r$ is better than doing $w$, but she does not know it. In fact, no one can ever claim to know something in this realm. (Venturinha 2018: 92)

One first issue with this proposal is that it does not address genuine cases of ethical akrasia. Plausibly, if the subject is aware that she does not know whether $r$ is better than $w$, she should not judge that this is so. It can be argued that a subject is not in a position to have a rational full belief that $p$ (i.e. to judge that $p$ ) if she knows that she is not in a position to know that $p .{ }^{1}$ More specifically, if the subject is aware that her (rational) doubts prevent her from knowing for sure whether she ought to do $r$ (or rather $w$ ), then she is not in a position to rationally judge, or fully believe, that she ought to do $r$. I take it that the interesting cases of akrasia are those where the agent knows (or at least, rationally believes) that she ought to do $r$, but nevertheless chooses to do $w$. This form of akrasia would remain unexplained by Venturinha's epistemic account. Rather, Venturinha's proposal seems to concern subjects that have to decide what to do in circumstances of pervasive uncertainty, without being sure whether they are actually

\footnotetext{
${ }^{1}$ Note that this requirement is weaker than a knowledge norm for belief like Williamson's (2000), according to which one may believe to $p$ only if she knows it.
} 
making the right decision. This type of ethical deliberation under uncertainty is surely worth exploring, but I do not think that it involves straightforward cases of akrasia.

Moreover, I think that generalized ethical scepticism can be resisted, even if one is sympathetic to the idea that ethical deliberation is context-sensitive. It is not clear to me that ethical particularism leads to the sceptical view that subjects cannot typically know, on a given occasion, what is the right thing to do. Particularism is committed to the claim that there are no general, universal, non-trivial rules that determine what is ethically right in each possible case (see, for instance, Dancy 2004). But this commitment is compatible with thinking that subjects are often be able to come to know what they ought to do on a particular occasion, after taking into account all relevant contextual information. Particularists can argue that such knowledge is not attained by applying general rules, but rather by manifesting a suitable ethical sensibility, or by being properly responsive to the reasons available in that particular situation. For example, a particularist may deny that there is a general ethical rule that decisively forbids lying in any possible situation, while at the same time acknowledging that, on a give specific case, it is ethically forbidden for a certain subject to lie. Surely, there are many contexts where we can know that it is wrong to enslave children!

\section{Akrasia and the Disclosure Principle}

A better picture of akrasia can be provided, I think, if we combine the Disclosure Principle with the idea that akratic subjects are conflicted or divided. As Venturinha notes (2018: 92), cases of akrasia involve a conflict of reasons. The subject recognizes the presence of conflicting reasons for alternative options. This does not mean, however, that akratic situations are ethical dilemmas. The reasons in favour of one of the options (say, $w$ ) may be recognized by the subject as stronger than the reasons for the other available options (say, $r$ ). This is why the subject judges that the winning option $(w)$ is the right thing to do, i.e. the option supported by the strongest reasons available. Nevertheless, the subject will remain aware of the existence of (weaker) reasons for the alternative option $r$. Such weaker reasons will present features of $r$ that make it somewhat good, desirable or worth choosing. Akrasia takes place when the subject's will falls under the attraction of these 
desirable features of $r$, even if she recognizes that the alternative option $w$ has other features that make it even more desirable. ${ }^{2}$

Imagine, for instance, that the subject is deciding whether to go to the cinema or to stay home sorting out bills as she promised to her flat mate. The fact that going to the cinema will be fun is a reason for the subject to go, whereas the fact that she promised her flat mate to sort out the bills is a reason for her to stay home instead. Assume that the subject concludes that her reasons to stay home are stronger than her reasons to go to the cinema. Still, she will keep being sensitive to the attractiveness of going to the cinema. The subject will be akratic if, against her better judgment, she ends up going to the cinema, in response to the desirable features of doing so (i.e. it will be a lot of fun!).

The Disclosure Principle, as I have interpreted it, offers a nice explanation of how this type of akrasia can arise. ${ }^{3}$ According to my way of fleshing out the principle, right actions are those that the subject considers to be fitting objects of attitudes of approval. In a Lewisian spirit, let us add a motivational dimension to our judgments about the fittingness of evaluative attitudes. Assume then that, when a subject considers that it is fitting to approve of a certain action available to her, she desires to approve of it. Moreover, assume that, when the subject desires to approve of an action available to her, she desires to be motivated to perform it (i.e. she desires to desire to do it). ${ }^{4}$ The resulting view is that right actions are those that the subject desires to desire to perform. Note that, on this view, even if judgments about the rightness of an action have motivational force, they will not always lead directly to motivation to perform the action judged to be rightthe link between the judgment and motivation to perform the action is often indirect. It may happen that the subject is not (yet) able to be motivated to do what she desires to be motivated to do. In these cases, judging that a given action is right may fail to directly motivate the subject to perform the action, but it will still motivate her to take steps to get to a position where she can be actually motivated to perform that action. Imagine, for instance, that I judge that I ought to become vegetarian, but I struggle to get myself to do it. My judgment that being vegetarian is the right thing to do can nevertheless motivate

\footnotetext{
${ }^{2}$ It is interesting to note that cases of epistemic akrasia seem much more difficult to find (Hurley 1993; Pettit and Smith 1996; Adler 2002; Owens 2002; Raz 2011). My suggestion is that this is so because epistemic reasons for (full) belief do not conflict with each other, unlike practical reasons: if a subject concludes that she has decisive reasons to fully believe that $p$, then she cannot rationally recognize the existence of (weighty) contrary reasons to disbelieve it. See González de Prado (forthcoming).

${ }^{3}$ For further discussion of higher-order desires in connection with akrasia, see for example Mele (1992); Pérez Carballo (2018).

${ }^{4}$ For the sake of simplicity, let us stipulate that there is no alternative available action the subject desires to approve of.
} 
me (at least to some extent) to undertake courses of action that are likely to make me more amenable to being directly motivated by the reasons in favour of vegetarianism. For instance, I can attend vegetarianism awareness events, or take a closer look at the prevalent conditions in animal farming. Hopefully, by undertaking these actions I will become a person able to be motivated to become a vegetarian in light of the reasons recommending doing so.

Thus, what is ethically right, from the current perspective of the subject, is not so much determined by the evaluative responses and motivational dispositions that she has as the person she is now, but rather by the evaluations and dispositions of the person that the subject desires to be. As Venturinha puts it, the Disclosure Principle is supposed to crystalize "what human beings, in their erratic nature, believe each time to be the best or worst picture they want to eternalize of themselves" (2018: 93).

Now, it can be difficult to become the person you aspire or desire to be. Often, this is not just a matter of an instantaneous, voluntary decision. Many of us are familiar with the experience of aiming to become a new person, while still manifesting some of the behaviours, dispositions and sensibilities of the old self we desire to leave behind. It is not always easy to get rid of character traits and dispositions that you disapprove of and wish to modify. Desiring to do something does not always immediately translate into achieving it, and, in particular, desires to desire certain things can be hard to satisfy. Personal transformation tends to be a lengthy process.

I want to suggest that akrasia involves this type of ongoing personal transformation and revision. In akratic situations, the subject desires to be a different type of person than she currently is - at least, she desires to have different dispositions and personality traits. Being the person she still is, the subject cannot properly respond to certain reasons yet (for instance, she cannot be moved to refrain from having fun in the cinema in order to fulfil her promise to her flat mate). However, the subject recognizes the desirability of becoming a person able to respond properly to the relevant reasons, and thereby to be motivated to act as those reasons recommend. In this way, the akratic subject judges that the right thing to do is to perform an action which a better, desirable self (but not her current one) would be motivated to perform.

To be sure, akratic subjects described in this manner can still be said to be irrational, insofar as they manifest a failure to respond properly to considerations recognized by themselves as good reasons in favour of some action (in the example above, the akratic subject recognizes that, on balance, her reasons decisively support staying 
home, and yet she is tempted to go to the cinema instead). After all, it can be argued that irrationality is precisely a matter of failing to respond to what from your perspective appear to be your reasons (see Schroeder 2007; Way 2009; Parfit 2011; Alvarez 2018; González de Prado 2018). Yet, seen under the light of the discussion in the previous paragraphs, these irrational akratic individuals are at least intelligible. The challenge posed by akrasia is not to show that akratic states can be rational, but rather to explain how they can take place in individuals with ordinary psychologies. ${ }^{5}$

\section{References}

Adler, J. (2002). Akratic believing? Philosophical Studies, 110(1), 1-27.

Alvarez, M. (2018). Reasons for action, acting for reasons, and rationality. Synthese, 195(8), 3293-3310.

Ayer, A. J. (1936/1971). Language, truth and logic. Harmondsworth: Penguin.

Blackburn, S. (1984). Spreading the word. Oxford: Clarendon Press.

Blackburn, S. (1993). Essays in quasi-realism. Oxford: Oxford University Press.

Dancy, J. (2004). Ethics without principles. Oxford: Oxford University Press.

Gibbard, A. (1990). Wise choices, apt feelings: A theory of normative judgment. Cambridge, MA: Harvard University Press.

González de Prado, J. (2018). Rationality, appearances, and apparent facts. Journal of Ethics \& Social Philosophy, 14(2), 83-111.

González de Prado, J. (forthcoming). No reasons to believe the false. Pacific Philosophical Quarterly. https://doi.org/10.1111/papq.12271.

Harman, G. (1975). Moral relativism defended. Philosophical Review, 84, 3-22.

Hurley, S. (1993). Natural reasons. Oxford: Oxford University Press.

Lewis, D. (1989). Dispositional theories of value. Aristotelian Society Supplementary Volume, 63(1), 113137

McDowell, J. (1998). Mind, value, and reality. Cambridge, MA: Harvard University Press.

Mele, A. R. (1992). Akrasia, self-control, and second-order desires. Noûs, 26(3), 281-302.

Owens, D. (2002). Epistemic akrasia. The Monist, 85(3), 381-397.

Parfit, D. (2011). On what matters. Oxford: Oxford University Press

Pérez Carballo, A. (2018). Rationality \& second-order preferences. Noûs, 52(1), 196-215.

Pettit, P., \& Smith, M. (1996). Freedom in belief and desire. The Journal of Philosophy, 93(9), 429-449.

Raz, J. (2011). From normativity to responsibility. Oxford: Oxford University Press.

\footnotetext{
${ }^{5}$ This work has been supported by the Spanish Government research project FFI2017-89639-P and the Portuguese Foundation for Science and Technology project PTDC/MHC-FIL/0521/2014 ("Values in Argumentative Discourse"). Thanks to Nuno Venturinha and to the participants in a symposium on his book Descriptions of Situations at NOVA University of Lisbon.
} 
Scanlon, T. (1998). What we owe to each other. Cambridge, MA: Harvard University Press.

Schroeder, M. (2007). Slaves of the passions. Oxford: Oxford University Press.

Stevenson, C. L. 1944. Ethics and language. New Haven: Yale University Press.

Street, S. (2010). What is constructivism in ethics and metaethics? Philosophy Compass, 5, 363-384.

Venturinha, N. (2018). Description of situations: An essay in contextualist epistemology. Cham: Springer.

Way, J. (2009). Two accounts of the normativity of rationality. Journal of Ethics and Social Philosophy, 4, $1-8$.

Wedgwood, R. (1997). The essence of response-dependence. European Review of Philosophy, 3, 31-54.

Wiggins, D. (1987). Needs, values and truth. Oxford: Oxford University Press.

Williamson, T. (2000). Knowledge and its limits. Oxford: Oxford University Press. 